\title{
The Responsibility of Indonesia for Deforestation Based On United Nations Convention On Biological Diversity
}

Christina Nitha Setyaningati ${ }^{1}$, Asilah $\mathrm{AS}^{2}$, Cecealia Zefania Tandiono ${ }^{3}$, Elvira Anastasia Cempaka ${ }^{4}$, Muhammad Rizki ${ }^{5}$

1 Faculty of Law, Universitas Airlangga, christina.nitha@gmail.com

2 Faculty of Law, Universitas Airlangga, sisilbvn@gmail.com

3 Faculty of Law, Universitas Airlangga, cecealia.zefania@gmail.com

${ }^{4}$ Faculty of Law, Universitas Airlangga, chivylovy@gmail.com

${ }^{5}$ Faculty of Law, Universitas Airlangga, emerzeki@gmail.com

\section{Abstract}

Introduction to The Problem: Indonesia is one of the participants of the United Nations Convention On Biological Diversity Or better known as UNCBD. Indonesia has also ratified this UNCBD into Act No. 5 of 1994 on the Ratification of the UNCBD. By this ratification, Indonesia has obligations and responsibilities that must be carried out under the provisions of the Convention. One is about the protection of the environment; in this case, is deforestation relating to biodiversity. Based on UNCBD, Indonesia also should make the implementing Law for the ratification. The problem is that Indonesia has no implementing regulation yet for the ratification.

Purpose/Objective Study: The purpose of this paper is to find out the concept of environmental protection; in this case, deforestation based on the UNCBD and positive law in Indonesia. It also suggests what forms of Indonesia's responsibility and what implementation steps to overcome the deforestation occurring in Indonesia.

Design/Methodology/Approach: The research employs the qualitative method based on a normative juridical study. Additionally, the authors used two approaches, which are conceptual and the statute approach.

Findings: Indonesia has not explicitly made an implementing law for Act No. 5 of 1994 as a ratification law of UNCBD. For that reason, it is the government responsible for making the implementing regulation. The Indonesian government should pay attention to the previous legal-made experience regarding the other ratification before UNCBD. The simple steps, but the main base reasons are using consideration phrase of the inexistence of implementing regulation for the ratifiedUNCBD and also the government responsibility to oblige the ratification.

Paper Type: Research Article

Keywords: liabilities, deforestation, biological diversity, UNCBD

\section{Introduction}

Nowadays, national development pays less attention to the environmental aspect, especially the utilization of the forest. Excessive forest utilization causes various 
problems to occur. Even it is estimated that approximately 18.7 thousand kilometers of forests disappear every year, it is as broad as 27 football fields each minute. Forest is the name for a large area packed with plants. The existence of forests is crucial, considering that forests have many benefits, starting from ecological benefits, socio-cultural benefits, and also economic benefits (Kamilia \& Nawiyanto, 2015). The forests in Indonesia are crucial for life on earth. Forests function as energy reserve on earth and play an essential role as weather control and water cycle regulator (Sutoyo, 2010).

Nowadays forests face deforestation threat that keeps increasing. While the nonforest area keeps increasing each year, it means that there has been a change of land usage from the forest into non-forest (Sari, Subiyanto, \& Awaluddin, 2014). From this changing then came of what so-called as deforestation. Deforestation is damaging the forests due to human activities such as logging, cutting down trees for fuel, cutting and burning agriculture, clearing land for grazing livestock, mining operations, oil extraction, dam construction, and urban sprawl or other types of development and population expansion. Deforestation of forests is a result of the dynamics of land use along with the process of economic development (Amalia, 2010).

The deforestation will harm the forests we utilize so far and endanger various natural resources and biological diversity (Djaenudin, Oktaviani, Hartoyo, \& Dwiprabowo, 2018). Deforestation can be in various forms, such as forest burning, logging to open agricultural land, farm, and construction, logging without preserving the forests, and degradation due to climate change. Mostly, deforestation in Indonesia resulted from a corrupt political and economic system, which considers natural resources, especially forests, as a source of income that exploited for political interests and personal gain (Arif, 2016).

One of the results of discussion by the world community regarding the importance of environmental protection is the United Nations Convention on Biological Diversity of 1992. The Convention discusses protection and settings on biological diversity, which approved and ratified by the convention participating countries. One of the convention participants that has approved and ratified the convention is Indonesia. In this case, it is the state responsibility to protect and guard the forest environment against any attempts that will harm the environment itself. Legal principles on state responsibility are a situation where, and a principle in which, the harmed country will provide compensation for the loss (Starke, 2010). In 2012, Indonesia was estimated to have lost approximately 840.000 hectares of its forests, and Brazil has lost 460.000 hectares of its forests. The forest loss is estimated to happen because of deforestation, namely forest fire, illegal logging, and forest clearing as agricultural land. 


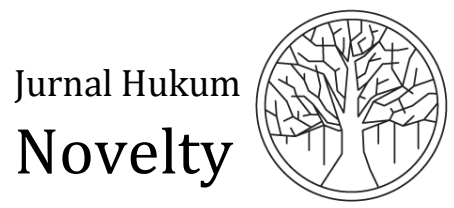

Volume 10, Issue 01, 2019, pp. 74-84

Indonesia is one of the participants that ratify the UN Convention on Biological Diversity. Indeed, by ratifying the convention, Indonesia has some rights and responsibilities to be performed. The responsibility is to make related regulations applicable in national law based on the UN Convention on Biological Diversity. The Convention on Biological Diversity is also related to the laws in Indonesia. The laws are, among others, Act No. 32 of 2009 regarding Environmental Management and Protection, Act No. 41 of 1999 regarding Forestry.

In the Convention on Biological Diversity and the positive law of Indonesia, a juridical conflict occurs. On the other hand, with its massive biological diversity, Indonesia is also considered as one of the most accessible places to find wildlife crime (Lembaga Pengembangan Hukum Lingkungan, 2015). We can found the conflict when we pay attention to the term of sovereign right. In the UN Convention, biological diversity is the sovereign right of the state (Wartini, 2005). However, in practice, Indonesia has to comply with international law regulations in order to implement the sovereign right (Hunter, 2013). This practice is in contrast to Indonesia's law that by complying international regulations is decreasing government autonomy and its independence to govern and regulate the most suitable rules internally (Ayoob, 2002). In addition to the juridical conflict, Indonesia has not made any implementing laws of the Convention of Biological Diversity. Therefore, this study seeks the existing laws with Ratified-Convention by Indonesia.

Moreover, this study also sees the juridical steps of the needs of Indonesia's legal material towards the Convention on Biological Diversity. The arising problems are, first, how is the concept of environmental protection, in this case, deforestation based on the UN Convention on Biological Diversity and positive law in Indonesia? Second, what are the forms of Indonesia's responsibility and implementation steps as a member that has ratified the UN Convention on Biological Diversity towards deforestation that is occurring in the Republic of Indonesia?

\section{Methodology}

The type of research method used by the writers in this research was juridical normative. It means analyzing statutory regulations as a form of a written legal norm, as well as theories, principles, and international agreements related to the subject matter of the study (Sunggono, 2012). The research used the conceptual approach by analyzing the concept of Indonesia's implementation and its responsibility for deforestation based on national regulation and the Convention on Biological Diversity. Additionally, this investigation also used statute approach by analyzing statutory regulations related to legal issues, especially in the field of International Law. Both approaches used in this article because the object of the study was an international agreement that applicated as a law for the parties agreeing on it. 
The data materials used in this research are three categories: primary, secondary, and tertiary. The primary legal materials used in the study included statutory regulations, regulations, International Convention, and official documents of the state. In the study, the primary legal materials the writers used were the Convention on Biological Diversity of 1992 and Act No. 32 of 2009 regarding Environmental Management and Protection. Secondary legal materials are all publications regarding the topic, such as journal or literature written by experts in International Law. Tertiary legal materials are legal materials used to provide guidance and explain the primary and secondary legal materials. The tertiary legal materials used by the writers in the study were from a website or Black Law Dictionary.

The data analysis technique used was descriptive analysis. It based on research problem solving and also analysis of written provision in the form of regulations or theories (Soekamto, 2012). Therefore, the analysis is presented descriptively, where the result of the study aims to obtain comprehensive illustration but still systematic, especially regarding the problems discussed in the study.

\section{Analysis and Results}

The Concept of Environmental Protection on Deforestation Based on the UN Convention on Biological Diversity and Positive Law in Indonesia

Forest is an ecosystem unit in the form of a vast land containing biological natural resources which are dominated by trees in an alliance of natural environment, which linked one after another. Forests function as carbon dioxide sinks, animal habitats, current hydrological modulators, and soil conservation and are one of the most critical aspects of the earth's biosphere. Forests are complex ecosystems that influence almost every species on earth. Loss of forest cover will cause both local and world scale disasters. By that means, it will then come the term of deforestation.

Indonesia famously called as the lungs of the world for its large forest environment scattered in its islands. However, this 'lungs' are not in good shape anymore (Hafidz, 2011). The condition caused by the loss of forest cover or in another term called deforestation. Deforestation in Indonesia caused by numerous main factors: 1) the conversion of the forest for land usage as agricultural land; 2) forest fire; 3) Illegal logging; and 4) climate change.

Forest fire is an event where fire engulfs vegetated fuel, and it happens in the forest area that spreads freely and uncontrollably. Forest fires were initially thought to occur naturally, but humans likely play a role in starting fires in the last millennium (Desri,2016:277). Wetlands International states that based on the facts, almost all forest fires in Indonesia caused by human activities, whether intentional or unintentional, and there has been no evidence of natural fires (Pinem, 2016).

Illegal logging recognized as being the most critical problem in the forestry sector. It causes damage to forest resources in terms of both the quality and quantity of 


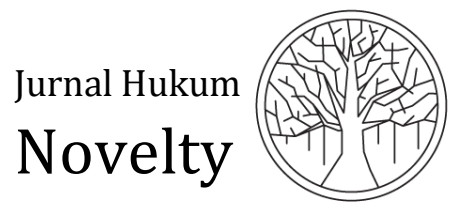

Volume 10, Issue 01, 2019, pp. 74-84

species composition, regeneration, land quality/productivity, and disrupts the supply of the log (Narindrani, 2018). Illegal logging defined as "illegal, unofficial, or unlawful logging activities" (Lena, 2016). The illegal logging activities, among others, done by workers who are coming from the community around the forest or outsiders. Other doers of this illegal act are like investors, including dealers, holders of logging concession, holders of wood utilization permit, or illegal wood buyers from processing industries. Unfortunately, the act also sourced from government officials, either civil or military parties, including specific legal enforcers and legislative officials (Runturambi, 2003).

Indonesia is one of the countries that have ratified the UN Convention on Biological Diversity. Indonesia is the eighth country out of 157 countries that have signed the convention (Yulia \& Zainol, 2013). On the basis, Act No. 5 of 1994 regarding Ratification of the UN Convention on Biological Diversity considers that biological diversity in the world, especially in Indonesia plays an essential role for the continuation of evaluation process and maintenance of ecosystem balance and biosphere life system. The existence and sustainability of biological diversity, including ecosystem, types, and genetics, including animals, plants, and microorganisms, need to be secured for life. However, biological diversity is experiencing real decrease and loss because certain humans activities cause disturbance of life system balance on earth that in turns will disturb the sustainability of human life.

Biological diversity classified into three categories, namely species diversity, biological diversity, and community diversity. The three levels of biological diversity are essential for the sustainability of life on earth (Sunarmi, 2014). Recognition of the role of community with traditional characteristics reflected from the lifestyle. It is also recognized the critical role of human to utilize the richness of diversity and the intention to equitably distribute the benefits in the usage of traditional knowledge through innovations and practices related to sustainable conservation of biological diversity and its utilization. Extensive utilization of plant diversity potentials supports broad conservation activities in state-owned forest area or human-developed environments like the garden, yard, community forest, and family forest. Conservation of plant biological diversity in state-owned forest area is expected to be more effective because various supporting instrument such as land status, policy and regulation, management organization unit, and routine funding source are available (Njurumana, Marsono, Irham, \& Sadono, 2014).

When it viewed philosophically, Act No. 41 of 1999 regarding Forestry bases its consideration on the forest as a gift of the Almighty God bestowed upon Indonesian people. It is a part of wealth owned by Indonesia that has given multipurpose benefits for humans. Thus, it should be thankful for, managed, and utilized optimally, and also preserved it as much as possible for the people's prosperity for the present generation and their future (Ahmad, 2014). Therefore, the existence of forest needs 
to be maintained optimally, its carrying capacity needs to be maintained sustainably, and managed with noble, fair, wise, transparent, professional, and accountable characters.

Act No. 32 of 2009 regarding Environmental Protection and Management is the guarding law in the management of natural resources. The principles of environmental protection and management are responsible state, preservation, sustainability, harmony and balance, integration, benefits, care, justice, ecoregion, biological diversity, participative, local wisdom, good governance, and regional autonomy. So, based on those environment protection principles, environmental protection and management have many goals. The first goal is protecting the area of the Republic of Indonesia from environmental pollution and damage. This protection will then secure the safety, health, and life of humans. Securing those three is also securing the sustainability of living things and the preservation of the ecosystem; which it will maintain the preservation of environmental functions. Another aim is achieving harmony and balance of the environment for fulfilling the justice of the present and future generation, and also protecting the rights on the environment and human rights. The other goals of the protection and management are wisely controlling the utilization of resources, realizing sustainable development, and anticipating global environmental issues.

Table 1. Comparison of UNCBD and Positive Law of Indonesia (Act No. 32 of 2009 regarding Environmental Protection and Management)

\begin{tabular}{|c|c|c|c|}
\hline Comparison & UNCBD & $\begin{array}{l}\text { Positive Law of } \\
\text { Indonesia }\end{array}$ & Remarks \\
\hline Jurisdiction & $\begin{array}{l}\text { The state has a } \\
\text { sovereign right on } \\
\text { biological diversity } \\
\text { (Article 3) }\end{array}$ & $\begin{array}{l}\text { The state has } \\
\text { sovereignty on } \\
\text { biological diversity } \\
\text { (Article } 33 \text { verse ( } 3 \text { ) of } \\
\text { the Constitution of the } \\
\text { Republic of Indonesia } \\
\text { Year 1945) }\end{array}$ & $\begin{array}{l}\text { The difference is } \\
\text { visible from the } \\
\text { jurisdiction } \\
\text { principle followed } \\
\text { in UNCBD and } \\
\text { Positive Law of } \\
\text { Indonesia. }\end{array}$ \\
\hline Goals & $\begin{array}{l}\text { The goals of } \\
\text { UNCBD are } \\
\text { provided in Article } \\
\text { 1, namely: } \\
\text { Biological diversity } \\
\text { conservation, } \\
\text { sustainable } \\
\text { utilization of } \\
\text { components as well } \\
\text { as fair and equal }\end{array}$ & $\begin{array}{l}\text { The goals of Law No. } 32 \\
\text { of } 2009 \text { regarding } \\
\text { Environmental } \\
\text { Protection and } \\
\text { Management are in } \\
\text { Article 3, namely: } \\
\text { a. To protect the area } \\
\text { of the Republic of } \\
\text { Indonesia from } \\
\text { environmental }\end{array}$ & $\begin{array}{l}\text { We can see that } \\
\text { the goals of Law } \\
\text { No. } 32 \text { of } 2009 \\
\text { refer to the } \\
\text { national interest, } \\
\text { while the goals of } \\
\text { UNCBD refer to } \\
\text { international } \\
\text { interest. }\end{array}$ \\
\hline
\end{tabular}




\begin{tabular}{|c|c|c|c|}
\hline & $\begin{array}{l}\text { distribution of } \\
\text { profits obtained } \\
\text { from utilization of } \\
\text { genetic resources, } \\
\text { including through } \\
\text { adequate access to } \\
\text { genetic resources } \\
\text { and with effective } \\
\text { technology } \\
\text { transfer, and by } \\
\text { paying attention to } \\
\text { all rights on the } \\
\text { resources and } \\
\text { technology with } \\
\text { adequate fund. }\end{array}$ & $\begin{array}{l}\text { pollution and } \\
\text { damage; } \\
\text { b. To secure the safety, } \\
\text { health, and life of } \\
\text { humans; } \\
\text { c. To secure the } \\
\text { sustainability of } \\
\text { living things and the } \\
\text { preservation of the } \\
\text { ecosystem; } \\
\text { d. To maintain the } \\
\text { preservation of } \\
\text { environmental } \\
\text { functions; } \\
\text { e. To achieve harmony } \\
\text { and balance of the } \\
\text { environment; } \\
\text { f. To secure the } \\
\text { fulfillment of justice } \\
\text { for the present } \\
\text { generation and } \\
\text { future generations; } \\
\text { g. To secure the } \\
\text { fulfillment and } \\
\text { protection of rights } \\
\text { on the environment } \\
\text { and human rights; } \\
\text { h. To control the } \\
\text { utilization of } \\
\text { resources wisely; } \\
\text { i. To realize } \\
\text { sustainable } \\
\text { development; } \\
\text { j. To anticipate global } \\
\text { environmental } \\
\text { issues. }\end{array}$ & \\
\hline Principles & $\begin{array}{l}\text { In UNCBD, the } \\
\text { principles used are } \\
\text { under the UN } \\
\text { Charter and the } \\
\text { principles of other } \\
\text { international laws, } \\
\text { provided in Article }\end{array}$ & $\begin{array}{l}\text { The principles of Law } \\
\text { No. } 32 \text { of } 2009 \\
\text { regarding } \\
\text { Environmental } \\
\text { Protection and } \\
\text { Management are in } \\
\text { Article 2, namely: }\end{array}$ & $\begin{array}{l}\text { The principles in } \\
\text { UNCBD are the } \\
\text { principles under } \\
\text { the existing of } \\
\text { international laws } \\
\text { and UN Charter, } \\
\text { while the }\end{array}$ \\
\hline
\end{tabular}




\begin{tabular}{|c|c|c|c|}
\hline & 3 of UNCBD. & $\begin{array}{l}\text { a. State responsibility } \\
\text { b. Preservation and } \\
\text { sustainability } \\
\text { c. Harmony and } \\
\text { balance } \\
\text { d. Integration } \\
\text { e. Benefits } \\
\text { f. Care } \\
\text { g. Justice } \\
\text { h. Ecoregion } \\
\text { i. Biological diversity } \\
\text { j. Polluters pay } \\
\text { k. Participative } \\
\text { l. Local wisdom } \\
\text { m. Good governance } \\
\text { n. Regional autonomy }\end{array}$ & $\begin{array}{l}\text { principles in Law } \\
\text { No. } 32 \text { of } 2009 \\
\text { are following the } \\
\text { national laws of } \\
\text { Indonesia. }\end{array}$ \\
\hline $\begin{array}{l}\text { State } \\
\text { Responsibility }\end{array}$ & $\begin{array}{l}\text { In UNCBD, state } \\
\text { responsibility } \\
\text { refers to } \\
\text { preventive } \\
\text { measures. The } \\
\text { parties in the } \\
\text { Convention are } \\
\text { required to take } \\
\text { preventive } \\
\text { measures against } \\
\text { any harmful } \\
\text { impacts and } \\
\text { improve the social } \\
\text { settings for various } \\
\text { emergency actions } \\
\text { or unexpected } \\
\text { events. There are } \\
\text { also efforts of } \\
\text { compensation and } \\
\text { payment, including } \\
\text { recovery and } \\
\text { compensation for } \\
\text { biological diversity } \\
\text { damage that has } \\
\text { happened (Article } \\
\text { 14). }\end{array}$ & $\begin{array}{l}\text { In positive law of } \\
\text { Indonesia, state } \\
\text { responsibility } \\
\text { performed in various } \\
\text { ways. Act No. } 32 \text { of } \\
2009 \text { regarding } \\
\text { Environmental } \\
\text { Protection and } \\
\text { Management, the state } \\
\text { governs about } \\
\text { preventive and } \\
\text { repressive measures } \\
\text { namely by Preparation } \\
\text { of Environmental } \\
\text { Protection and } \\
\text { Management Plan (Act } \\
\text { No. } 32 \text { of } 2009 \text {, Article } \\
\text { 9-11), settings of } \\
\text { environment utilization } \\
\text { (Act No. } 32 \text { of } 2009 \text {, } \\
\text { Article } 12 \text { ), control of } \\
\text { environmental } \\
\text { pollution and damage, } \\
\text { also regarding } \\
\text { environmental } \\
\text { maintenance }\end{array}$ & $\begin{array}{l}\text { Responsibility in } \\
\text { UNCBD } \\
\text { performed by } \\
\text { international } \\
\text { cooperation. }\end{array}$ \\
\hline
\end{tabular}


Form of Responsibility of Indonesia and Implementation Framework or Steps as a Participant that Has Ratified the UN Convention on Biological Diversity towards Deforestation

After ratifying UNCBD into national law of Indonesia, the responsibility of Indonesia for UNCBD does not stop just like that. Indonesia that is bound to the regulations of convention and protocol of UNCBD has to implement the provisions stated in UNCBD. Not only implanting the provisions of UNCBD, but Indonesia also has to make implementing regulations for Law No. 5 of 1994 regarding Ratification of the United Nations Convention on Biological Diversity. Indeed, Indonesia has made some laws related to environment and biological diversity, especially regarding deforestation as a part of biological diversity, such as Act No. 32 of 2009 regarding Environmental Protection and Management, Act No. 41 of 1999 regarding Forestry, and Act No. 18 of 2013 regarding Deforestation Prevention and Eradication. However, these laws are not in an actual substance which implements the UNCBD's provisions.

Therefore, the Law on Ratification of UNCBD (Act No. 5 of 1994) regarding the Ratification of the UNCBD does not have an appropriate and suitable implementing regulations yet. So, Indonesia needs to make appropriate implementing regulations as a part of the responsibility of Indonesia that has ratified UNCBD. Because in UNCBD, there are some provisions in which requiring Indonesia to make implementing regulations based on what contained in UNCBD.

Previously Indonesia also had signed and ratified Tokyo Convention 1963, The Hague Convention 1970, and Montreal Convention 1971. All of the conventions have been signed and ratified in Act No. 2 of 1976 regarding Ratification of Tokyo Convention 1963, The Hague Convention 1970, and Montreal Convention 1971. The ratified-conventions already has the implement regulations to expedite the implementation of the conventions into Indonesia's laws. However, it is different from UNCBD, which only has ratified status in Act No. 5 of 1994, but no implement regulations under this Act.

Indonesia's government has to refer to previously Acts which ratified some of the UN Convention with its complementary regulation for applying those Acts. Some of the example the government should pay attention are Act No. 4 of 1979 regarding Amendment and Addition of Some Articles in Criminal Code in Connection with Expansion of the Applicability of Criminal Laws, Flight Crime, and Crime against Flight Facilities/Infrastructures. This Act is an implementation regulation under Act No. 2 of 1976 regarding the Ratification of the Tokyo Convention of 1963. It also covers others that are The Hague Convention of 1970 and the Montreal Convention of 1971. So, these regulations are well-made law for its completeness between the ratification law and its implementer regulation. 
From that base, firstly, we need to pay further attention to the reasons for making the implementing regulation of Act No. 4 of 1994. Looking backward, we could see that Act No. 4 of 1976 explaining the reasons of this Act for having implementing regulation in its consideration. The main reason is that there is inexistence of specific regulation applied to overcome the crime against flight and flight facilities/infrastructures. Using this outlook, we can employ the experience of previously made regulation for making the applying regulation of Act No. 5 of 1994 regarding the Ratification of UNCBD. So, the legal drafters have to include the phrase of the inexistence of implementing regulation of Act No. 5 of 1994, specifically on the governing of biological diversity.

Other than using the inexistence of implementing regulation as the base of legal consideration, we could use the phrase of Indonesia's responsibility to preserve biological diversity as national treasures. Additionally, it is the obligation for Indonesia for having the rule to apply on biological diversity because of the willingness of the government to ratify the UNCBD.

\section{Conclusion}

The concept of protection in UNCBD refers to the interest of the international community. It observed from the adherence to the principle of sovereign right. Besides that, the concept of protection in outline is utilizing international cooperation to support each other and maintain biological diversity. The concept of protection in the positive law of Indonesia classified into some statutory regulations. In the laws, the concept of protection refers more to environmental protection that attaches importance to national interest first, as it looked from the terms of environment, Indonesia is sovereign as stated in Indonesia's Constitution of 1945.

Indonesia has not explicitly made any implementing regulation for the Law on Ratification of UNCBD (Act No. 5 of 1994). Because of the ratification, Indonesia has some obligations and responsibilities to implement the content of the convention, one of them is making a specific statutory regulation with consideration of ratification of UNCBD. The authors, in this case, recommend that the concept of environmental protection in this case deforestation related to biological diversity in UNCBD and the positive law of Indonesia has to adjust the international interest and national interest in a balanced way. That is why it is urgent to make specific implementing regulations which cover two interests; national and international. Because without it, in a simple conclusion, Indonesia is harming the international agreement as well as ignoring the preserving of national biological diversity.

\section{References}

Ahmad, R. (2014). Hukum Sumber Daya Alam Dalam Sektor Kehutanan. Jakarta: Sinar Grafika.

Amalia, R. (2010). Faktor Pembeda Kemampuan Brazil dan Indonesia dalam Menanggulangi Deforestasi pada Tahun 2001-2012. Jurnal Analisis Hubungan Internasional, 3(2), 795-816. 
Jurnal Hukum

Arif, A. (2016). Analisis Yuridis Pengrusakan Hutan (Deforestasi) dan Degradasi Hutan Terhadap Lingkungan. Jurisprudentie, 3(1), 33-41.

Ayoob, M. (2002). Humanitarian Intervention and State Sovereignty. The International Journal of Human Rights, 6(1), 81-102.

Djaenudin, D., Oktaviani, R., Hartoyo, S., \& Dwiprabowo, H. (2018). Analisis Peluang Keberhasilan Penurunan Laju Deforestasi: Pendekatan Teori Transisi Hutuan. Jurnal Penelitian Sosial Dan Ekonomi Kehutanan, 15(1), 15-29. https://doi.org/10.20886/jpsek.2017.15.1.15-29

Hafidz, J. (2011). Ekologi Konstitusioal (Green Constitutional) dan Kedaulatan Wilayah di Indonesia. Jurnal Hukum, XXVI(2), 533-549.

Hunter, D. B. (2013). International Environmental Law: Sources, Principles, and Innovations. In G. H. Paul (Ed.), Routledge Handbook of Global Environmental Politics (1st ed., pp. 345-355).

Kamilia, I., \& Nawiyanto. (2015). Kerusakan Hutan dan Munculnya Gerakan Konservasi Di Lereng Gunung Lamongan, Klakah 1999-2013. Publika Budaya, 1(3), 72-85.

Lembaga Pengembangan Hukum Lingkungan. (2015). Jurnal Hukum Lingkungan Indonesia. Jurnal Hukum Lingkungan Indonesia, 2(2).

Lena, E. (2016). Penegakan Hukum Terhadap Pelaku Tindak Pidana Illegal Logging di Wilayah Hukum Kabupaten Kampar Berdasarkan Undang-Undang Nomor 18 Tahun 2013 Tentang Pencegahan dan Pemberantasan Perusakan Hutan. Jurnal Online Mahasiswa Fakultas Hukum, 3(2), 1-15.

Narindrani, F. (2018). Upaya Masyarakat dalam Pencegahan dan Pemberantasan Pembalakan Liar di Indonesia. Jurnal Penelitian Hukum De Jure, 18(2), 241.

Njurumana, G. N., Marsono, D., Irham, \& Sadono, R. (2014). Konservasi Keanekaragaman Hayati Tanaman Pada Sistem Kaliwu di Pulau Sumba. Jurnal Manusia Dan Lingkungan, 21(1), 75-82.

Pinem, T. (2016). Kebakaran Hutan dan Lahan Gambut: Kajian Teologi Ekofeminisme. GEMA TEOLOGIKA, 1(2), 139.

Runturambi, J. S. (2003). Sisi Kriminologi Pembalakan Hutan Ilegal: Suatu Telaah Awal. Jurnal Kriminologi Indonesia, 3(I), 13-20.

Sari, C. P., Subiyanto, S., \& Awaluddin, M. (2014). Analisis Deforestasi Hutan di Provinsi Jambi Menggunakan Metode Penginderaan Jauh (Studi Kasus Kabupaten Muaro Jambi). Jurnal Geodesi Undip, 3(2), 28-43.

Soekamto, S. (2012). Pengantar Penelitian Hukum. Jakarta: UI Press.

Starke, J. G. (2010). Pengantar Hukum Internasional. Jakarta: Sinar Grafika.

Sunarmi, S. (2014). Melestarikan Keanekaragaman Hayati Melalui Pembelajaran di Luar Kelas dan Tugas yang Menantang. Jurnal Pendidikan Biologi Universitas Negeri Malang, 6(1).

Sunggono, B. (2012). Metodologi Penelitian Hukum. Jakarta: Rajawali Press.

Sutoyo, S. (2010). Suatu Tinjauan: Masalah dan Pemecahannya. Buana Sains, 10, 101-106.

Wartini, S. (2005). Implikasi Trip's Terhadap Konvensi Keanekaragaman. Ius Quia Iustum Law Journal, 12(30), 210-223.

Yulia, Y., \& Zainol, Z. A. (2013). Melindungi Keanekaragaman Hayati dalam Kerangka Protokol Nagoya. Mimbar Hukum, 25(2), 271-283. 